\title{
Egészségedre! Mókuskerék helyett! - Beszámoló a Nemzeti Egészségfejlesztési Intézet munkahelyi kampányáról
}

A report on the workplace health promotion campaign organized by the $\mathrm{Na}$ tional Institute for Health Development

\author{
Szerzők: Köteles Gábor $\bowtie$, Kutai Orsolya \\ Nemzeti Egészségfejlesztési Intézet
}

Beküldve: 2016.08.29.

Kulcsszavak: munkahelyi egészségfejlesztés, fizikai aktivitás, egészséges táplálkozás

Keywords: workplace health promotion, physical activity, healthy eating

\begin{abstract}
A munkahelyi egészségfejlesztés (MEF) olyan modern vállalati stratégia, amely megcélozza, hogy a betegségeket a munkahelyen előzzék meg, növeljék az egészségesség lehetőségeit és a munkahelyi jól-létet. $E$ célok elérése érdekében szélesebb eszköztárat kell bevetni mint a hagyományos munkavédelem, nevezetesen a munkaszervezet ez irányba történő orientálását és a személyiségfejlesztést. A MEF magában foglalja az összes olyan, az alkalmazottak, a munkaadók és a civil szervezetek által közösen hozott intézkedést, amelyek a dolgozók egészségét és jóllétét szolgálják.
\end{abstract}

Magyarországon az emberek egészsége jóval elmarad az ország gazdasági fejlettsége alapján várhatótól. Ma már számos kutatás bizonyítja, hogy a munkavállalók egészségének fejlesztése jócskán megtérülő befektetés, ugyanakkor azt is fontos hangsúlyozni, hogy az egészségükért a munkavállalók maguk tehetnek a legtöbbet. ${ }^{1}$

A munkahely kitüntetett helyszíne lehet az egészségfejlesztési programoknak, egyrészt a célcsoport itt könnyen, könnyebben mozgósítható, másrészt a munkavállalók a hagyományos egészségügy által a legnehezebben elérhetők, ugyanakkor több súlyos betegség szempontjából a legveszélyeztetettebbek. A részvétel valószínűségét az is növeli, hogy munkaidőben és helyben zajlanak az egészségfejlesztési programok. Az ilyen események hatékonyságát tovább fokozza, hogy a szervezéshez felhasználhatóak a munkahelyen már múködő, létező kommunikációs csatornák, a munkatársak közti kapcsolatok. A munkahelyen töltjük el éber óráink túlnyomó ré- szét. A munkahely tehát nagymértékben befolyásolja egészségünket és jól-létünket. Ezen a színtéren baleseteket és betegségeket lehet megelőzni, egészséges és biztonságos környezetet lehet kialakítani, olyan késztetések, ismeretek és módszerek terjeszthetők, amelyek az egészségtudatos magatartást és életmódot segítik megvalósítani. Közismert tény, a munkahelyen befolyásolt egészségtudat az élet más színterein is hatni fog.

A munkahelyi egészségfejlesztés a munkavállalókra irányul, de előnyei szerteágazóak: csökkennek a betegségekhez kapcsolódó kiadások, nő a vállalat termelékenysége. A munkahelyi egészségfejlesztés bizonyítható módon - egyértelműen kifizetődő tevékenység. Hasznából a vállalat (a munkáltató), a munkavállaló és a szociális ellátórendszer egyaránt részesül. A vállalati előny - a betegállományi statisztika hosszú távú javulásán túl - abban is jelentkezik, hogy rugalmasabbá válik a vállalkozás. Az egészséges, képzett és motivált munkaerővel ugyanis nö- 
vekszik az innovációs készség és a termelékenység. A jól végzett munkahelyi egészségfejlesztés javítja a vállalati képet az ügyfelek körében és a munkaerő piacon egyaránt. A pozitív munkahelyi környezet növeli a munkahelyi jól-létet és a munka iránti motiváltságot. Kiteljesedik az egészségtudat és ez előbb-utóbb hat a munkavállaló családi, baráti és lakókörnyezetére is. A munkavállalók elsősorban abból profitálnak, hogy a csökkenő megterhelés következtében ritkábban lépnek fel egészségi állapotra vonatkozó panaszok, vagy egészségkárosodásra utaló tünetek. Társadalmi haszonként a szociális ellátórendszerben is jelentkeznek előnyök. Csökkennek az egészségügyi és rehabilitációs kiadások, nő a munkában töltött évek száma, stb.

\section{A KAMPÁNY BEMUTATÁSA}

A Nemzeti Egészségfejlesztési Intézet 2015. április 1 és június 30 között a TÁMOP-6.1.3.B Népegészségügyi kommunikáció fejlesztése címú projekt keretein belül ingyenes munkahelyi egészségfejlesztési kampányt indított - Egészségedre! Mókuskerék helyett néven -, amelyben a munkavállalói csapatokat játékos formában kívánta ösztönözni az egészségesebb életmódra.

A program célja volt minél több emberben tudatosítani, hogy a mindennapokba könnyen beépíthető, apró, szórakoztató lépésekkel is sokat javíthat a közérzetén, egészségi állapotán. Emellett fontos cél volt, hogy a résztvevők a közösség támogató erejét is tapasztalják meg a kampány során. A program célcsoportja a többnyire ülőmunkát végző, szellemi foglalkozású munkavállalók voltak, de bárki jelentkezhetett, 3-7 fős munkahelyi csapatban. A részvétel mind a munkavállalók, mind a munkáltatók számára ingyenes volt.

Mivel tervezéskor tudható volt, hogy az időkorlátok miatt hosszútávon életmódváltás nem lesz elérhető a résztvevőknél, így a fentieken túl a programmal elsősorban egyfajta érzékenyítés, egy későbbi hoszszabb kampány megalapozása volt a cél.
A résztvevők 14 héten keresztül hétről hétre olyan könnyed, hasznos, az egészséges életmód kialakítását segítő, csapatban teljesítendő heti kihívásokat kaptak, amelyekkel általában több testmozgásra és egészségesebb táplálkozásra ösztönözték őket a szervezők. Például: „Díszítsétek ki a lépcsőházat és írjátok meg hány kalóriát égettetek el lépcsőzéssel a héten". A feladatok szakmai alátámasztása, indokoltsága - jelen esetben, hogy a lépcsőhasználók száma megnő abban az esetben, ha a lépcsőház gondozott és motiváló környezetet biztosít - a résztvevők számára a program blog oldalán minden esetben elérhető volt. ${ }^{2} 3$

A heti megmérettetések mellett a csapatok havi egy, a heti feladatoknál több előkészületet igénylő kihívást teljesítettek (például különböző sportágakban céges aktivitás szervezése). A havi feladatok között a lelki egészség témája is megjelent. A heti kihívások 80 százalékát kellett a csapatoknak teljesíteni, havi kihívásokból minden hónapban egyet.

Heti kihívásokra 1-1 példa

- Motiváld képekkel a munkatársaidat! - Készítsetek olyan képet, rajzot, infógrafikát, montázst, stb., amelyet a munkahelyi étkezőbe vagy büfé közelébe kitéve, az egészséges táplálkozásra ösztönzi a többi kollégát.

- Ülőgimnasztika - Csináljátok végig X-szer az alábbi gimnasztikát. Hajrá!

- Lépcsőzzetek! Szépítsétek ki a lépcsőházat! Tegyétek minél vonzóbbá munkahelyeteken a lépcsőházat, és érjétek el, hogy kollégáitok minél többet használják a lift helyett. Használjátok magatok is a lépcsőt, amennyit csak lehet. Írjátok meg, hány kalóriát égettetek így el.' Vágj és szeletelj! - A héten minden nap tisztítsatok meg és vágjatok fel legalább fejenként egy gyümölcsöt és egy zöldséget. Kínáljátok meg a nem csapattag kollégákat is és egyétek meg közösen. [1. ábra]

\footnotetext{
'A kihívással csatlakoztunk az Európai Liftmentes Naphoz (No Elevators Day) június 5-én. A programunknak köszönhetően Magyarország volt az egyik legaktívabb a tagállamok közül.
} 
Havi kihívásokra 1-1 példa:

- A jó dolgok csak jönnek! - Írjátok össze egy hétig minden nap, hogy milyen jó dolgok történtek veletek. Akár személy szerint, akár a csapatotokkal.

- Egészséges ebéd. - Szerezzétek meg a menzának a következő heti menüsorát. Nézzétek át a választékot, és a fogások felhasználásával minden napra állítsatok össze egy zsírszegény, egészséges ebédvariációt.

- Házi bajnokság - Fontos az egészséges versenyszellem! Szervezzetek házi bajnokságot vagy kupát egymás között. Minél többen vagytok, annál jobb. Hogy milyen sport legyen? Azt rátok bízzuk!

A kampány ideje alatt, a dohányzó csapattagok a program részeként, egy 90 napos online dohányzás leszokás támogatáson vehettek részt. Akik regisztráltak, 3 hónapon keresztül naponta hírlevelet kaptak, melyek segítségével könnyebben próbálkozhattak a leszokással. A leszokás támogatás három fő fázisának megfelelően - „Felkészülés a cigaretta letételére”, „A Függetlenség napja”, „A Függetlenség napja utáni új időszak" - tartalmaztak az e-mailek motivációs üzeneteket, tippeket a dohányzás abbahagyásához.

\section{1. ábra: Vágj és szeletelj!}

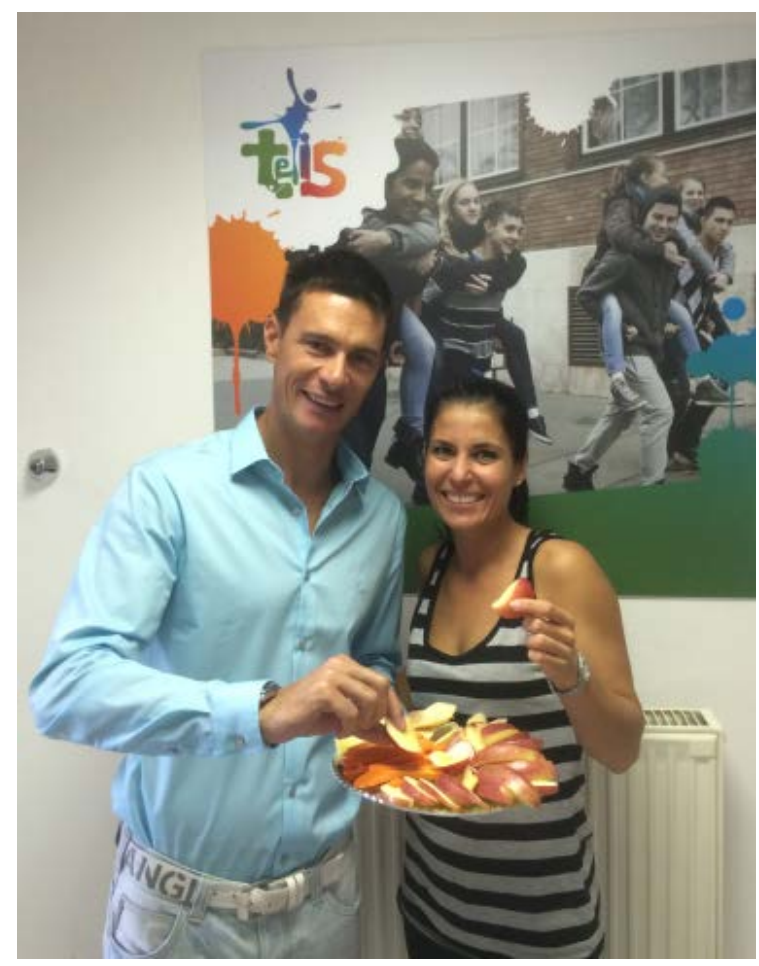

Forrás: „Egészségedre! Mókuskerék helyett” facebook oldal

2. ábra: Sétáló meeting gimnasztikával

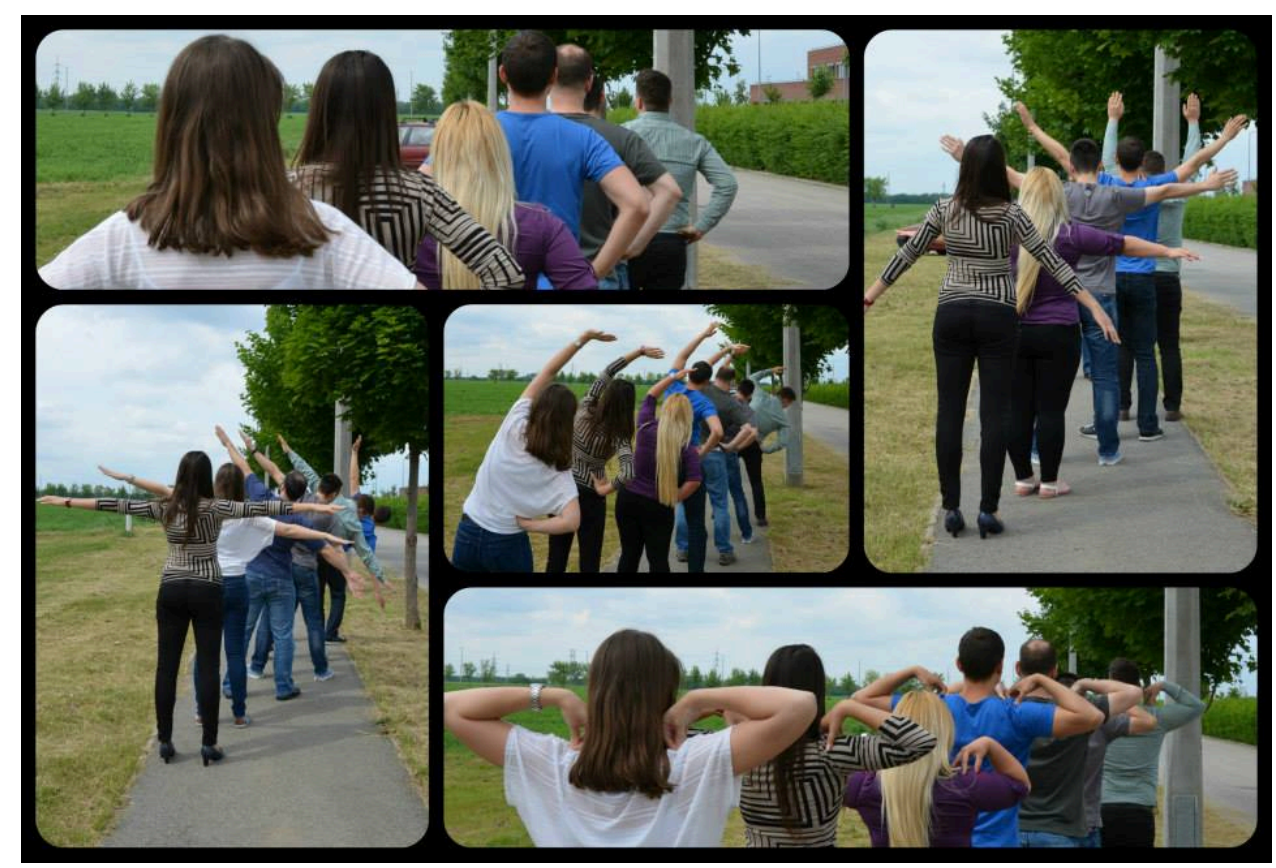

Forrás: „Egészségedre! Mókuskerék helyett” facebook oldal 
Fentieken túl egyéb célzott információkat is kaptak a résztvevők, pl. egészségügyi szűrésekre szóló ajánlásokat olvashattak, de megtudhatták, még mi mindent tehetnek egészségükért.

A kommunikációhoz több csatornát használtak a szervezők. A program kezdetén elindult az „Egészségedre! Mókuskerék helyett” blog, amelyen a résztvevők a kampány során folyamatosan inspiráló cikkeket és ötleteket találtak a kihívásokhoz és az egészségtudatosabb élet kialakításához. A csapatka- pitányok hetente email-ben kapták meg a feladatokat, és a hasznos tippeket az egészség megőrzéséhez. A kihívások teljesítését fényképpel, videóval dokumentálták a csapatok. [2. ábra és 3. ábra] A kétirányú kommunikáció támogatására, az ötletek, jó gyakorlatok megosztására egy interaktív facebook felület létrehozása volt a megoldás. ${ }^{4}$ A program kommunikációs partnere, a Juventus Rádió folyamatosan beszámolt az aktuális témákról, valamint saját csapatának felkészüléséről.

\section{3. ábra: Egészség frissitve, kattints rá!}

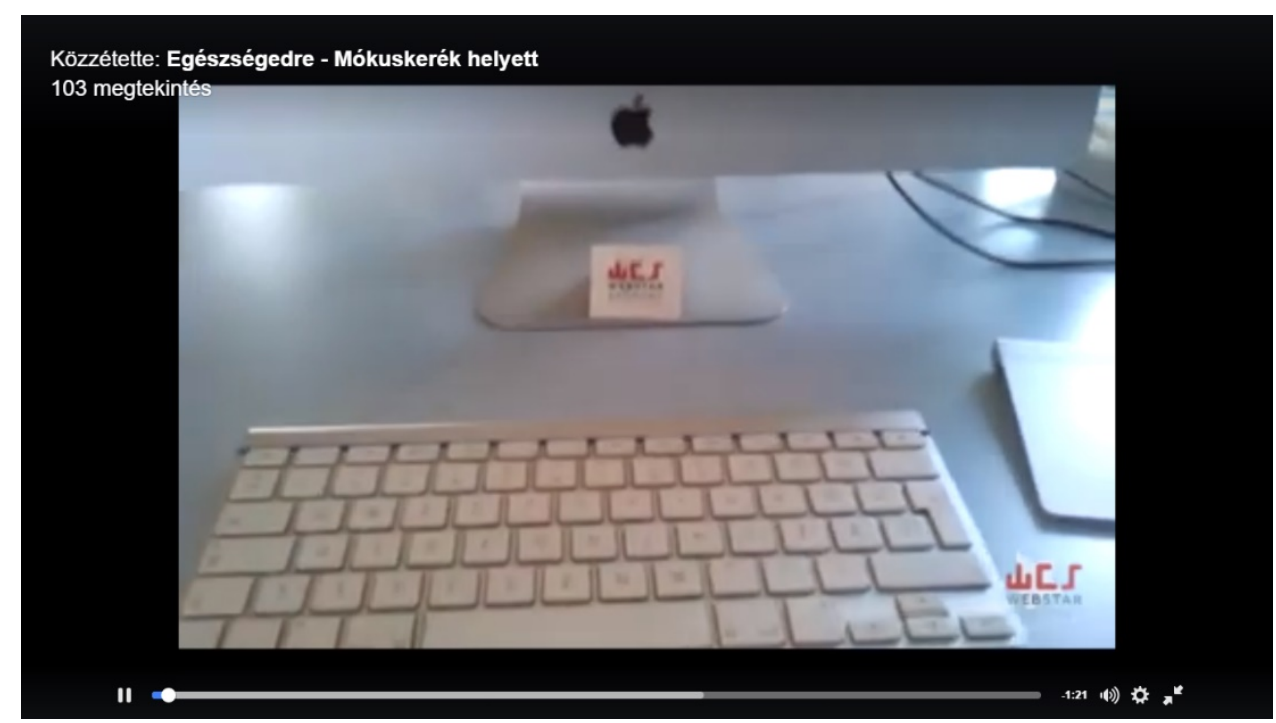

Forrás: „Egészségedre! Mókuskerék helyett” facebook oldal

\section{EREDMÉNYEK}

Az „Egészségedre! Mókuskerék helyett” programban 200 csapat, és közel 1500 fő vett részt az ország minden tájáról. Összesen 1455 kihívást teljesítettek a csapatok, közülük 80 mindegyiket sikeresen megoldotta. A feladatok végrehajtása során, a résztvevőkön keresztül közvetetten több mint 7500 embert értünk el, így a kampány egészségfejlesztési üzenetei számottevően nagyobb csoporthoz jutottak el, a közvetlenül megszólított csapattagoknál. A résztvevők amellett, hogy számos közös élménnyel és új információval gazdagodtak, jelentős lépéseket tettek az egészségtudatosabb életmód felé. Amenynyiben a csapatok sikeresen végrehajtották a kihívások több mint 80 százalékát, oklevelet kaptak és nyereményeket sorsoltak ki közöttük a szervezők, de díjban részesültek a legkreatívabb megvalósítók is.

Az összes kihívás, illetve a csapatoktól kapott 22 GBnyi beszámoló fotó és videó formájában megtalálható a kampány web és facebook oldalán.

A program folytatásaként a résztvevők közül 38 fő munkahelyi egészségkövet képzést kapott. A kétnapos kurzus célja volt, hogy az elsajátított elméletiés gyakorlati oktatásnak köszönhetően rá tudják majd venni az egészségkövetek munkatársaikat, hogy egészségesebben éljenek, fel tudják majd hívni munkahelyi környezetük figyelmét arra, a jobb közérzet elérése nem lehetetlen, csupán az első, apró lépéseket kell megtenni. 
A program sikerességét jelzik a résztvevőktől kapott visszajelzések, ezekből néhány példa:

"...gondoltam beszámolok arról, hogy mióta megy a mókuskerék, azóta bevezettük a munkahelyen a napi 10 perces tornát minden nap 10.30-kor."

"Heti egyszer megtartjuk a gyümölcs és zöldség napunkat, minden alkalommal megkínáljuk a többi munkatársunkat is!"

"...továbbra is sétálómeetingelünk, a fönökünket is meggyőzte a kezdeményezés."

„Régen rendszeresen relaxáltam, de már egy ideje nem teszem. Milyen jó, hogy felelevenítettétek! Azóta minden nap csinálom és a kollégákkal is leülünk heti egyszer."

„A liftmentes nap óta kizárólag lépcsőn járok, csak akkor használom a liftet, ha ügyfelek jönnek hozzám és őket kell kísérni."

\footnotetext{
${ }^{1}$ SANDERS, D.; CROWE, S. (1996). Overview of health promotion in the workplace. In:Health Promotion. Professional Perspectives. Ed. By: Scriven, A.; Orme, J. Macmillan Press Ltd., 199-211 p.

${ }^{2}$ www.mokuskerekhelyett.blog.hu (Elérve 2016.08.30.)

${ }^{3}$ http://www.cdc.gov/physicalactivity/worksite-pa/toolkits/stairwell/motivational signs.htm (Elérve 2016.08.30.)

${ }^{4}$ https://www.facebook.com/mokuskerekhelyett (Elérve 2016.08.30.)
} 